УДК 911:631.4(282.256.341)

РАЗНООБРАЗИЕ И ЗАКОНОМЕРНОСТИ ПРОСТРАНСТВЕННОЙ ОРГАНИЗАЦИИ ПОЧВ БАССЕЙНА ОЗ. БАЙКАЛ

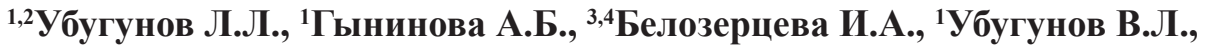
5 Доржготов Д., ${ }^{3}$ Сороковой А.А., ${ }^{1}$ Убугунова В.И., ${ }^{1}$ Бадмаев Н.Б., 1Балсанова Л.Д., ${ }^{1}$ Гончиков Б.Н., ${ }^{1}$ Цыбикдоржиев Ц.Ц.

${ }^{1}$ ФАНО России ФГБУН «Институт общей и экспериментальной биологии» СО РАН, Улан-Удэ, e-mail: ubugunovv@mail.ru;

${ }^{2}$ ФБОУ ВПО «Бурятская государственная сельскохозяйственная академия», Улан-Удэ;

${ }^{3}$ ФАНО России ФГБУН «Институт географии им. В.Б. Сочавы» СО РАН,

Иркутск, e-mail: belozia@mail.ru;

${ }^{4}$ ФБОУ ВПО «Иркутский государственный университет», Иркутск;

${ }^{5}$ Институт географии Академии наук Монголии, Улан-Батор, e-mail: batkhishig@gmail.com

Резкая пространственная смена климата в бассейне оз. Байкал, многообразие форм рельефа, кор выветривания, переотложенность рыхлого материала гравитационными, ветровыми и водными потоками, разнообразие растительного покрова обусловливают высокую степень неоднородности почвенного покрова. В его формировании большое участие принимают явления инверсии, миграции и интерференции, проникновение аридных почв по солярным склонам в горы, опускание мерзлотных горно-таежных почв в днища котловин, внедрение криоаридных и засоленных почв глубоко на север. Созданная почвенная карта бассейна оз. Байкал отражает общие географические закономерности распределения почв на этой территории. Наличие горных систем и их обширные пологонаклонные предгорья сглаживают контрасты в смене ландшафтов и почв в широтной зональности. Впервые показана роль горизонтальной зональности в формировании почвенного покрова высокогорий и среднегорий. Зональность горно-таежных почв проявляется в смене с севера на юг альфегумусовых почв криоземами. Специфика почвообразования на высоких равнинах и межгорных понижениях определяется дефицитом влаги, активной солнечной радиацией, поступлением холодных воздушных масс с гор в котловины. В этих условиях с севера на юг происходит смена дерново-серых почв каштановыми и криоаридными. Черноземы, дерново-подбуры и почвы органо-аккумулятивного отдела занимают нижние части склонов и подножия горных систем между горными и равнинными почвами. Их география определяется в большей степени вертикальной поясностью и экспозиционностью, нежели зональностью. Наибольшие площади их приурочены к предгорьям Прихубсугульских и Хангайского горных массивов.

Ключевые слова: почвы, почвенный покров, разнообразие, высокогорье, среднегорье, котловины, картографирование, бассейн оз. Байкал

\title{
VARIETY AND SPATIAL STRUCTURE OF SOILS OF THE LAKE BAIKAL BASIN
}

${ }^{1,2}$ Ubugunov L.L., ${ }^{1}$ Gyninova A.B., ${ }^{3,4}$ Belozertseva I.A., ${ }^{1}$ Ubugunov V.L.,

${ }^{5}$ Dorzhgotov D., ${ }^{3}$ Sorokovoy A.A., ${ }^{1}$ Ubugunova V.I., ${ }^{1}$ Badmaev N.B.,

${ }^{1}$ Balsanova L.D., ${ }^{1}$ Gonchikov B.N., ${ }^{1}$ Tsybikdorzhiev Ts.Ts.

${ }^{1}$ Institute of General and Experimental BiologySB RAS, Russia, Ulan-Ude, e-mail: ubugunovv@mail.ru; ${ }^{2}$ Buryat State Agricultural Academy, Ulan-Ude;

${ }_{3}^{3}$ Institute of Geography SB RAS named after V.B. Sochava, Irkutsk, belozia@mail.ru;

${ }^{4}$ Irkutsk State University, Irkutsk;

Institute of Geography and Geoecology of the Academy of Sciences of Mongolia, Ulaanbaatar

Sharp spatial change of climate in the basin of the Lake Baikal, variety of a relief, and weathering crust, redeposition of loose material by gravitation, wind, water, and vegetation diversity cause the high degree of the heterogeneity of the soil cover. The phenomena of inversion, migration and fallout of soil zones, penetration of arid soils along solar slopes to mountains, and permafrost-affected mountain taiga soils to the bottoms of hollows, pervasion of the cryoarid and salted soils deeply to the north take a large part in its formation. The created soil map of the basin of the Lake Baikal reflects the general geographical regularities of distribution of soils in this territory. Existence of mountain systems and their extensive pologonaklonny foothills smooth contrasts in change of landscapes and soils in the width zonality. The role of horizontal zonality in formation of a soil cover of highlands and middle mountains is shown for the first time. Zonality of the mountain taiga soils is become apparent in the change from the alfe-humus soils to cryosol from the north to the south. The specifics of soil formation on the high plains and intermountain depressions are defined by deficiency of moisture, active solar radiation, flows of cold air from the mountains into the hollows. In these conditions there is a replacing of soddy-gray soils by kashtanozems and cryoarid soils from the north to the south. Chernozems, soddy-podburs and soils of the organic accumulative department occupy the lower parts of slopes and the foot of mountain systems between mountain and plain soils. Their geography is defined more by the vertical zonality, and the slope exposition, than the latitudinal zoning. The largest areas of these soils are confined to the foothills near the lake Hubsugul and Hangay mountains.

Keywords: soils, soil cover, variety, highlands, middle mountains, hollows, mapping, basin of the Lake Baikal

Экологические проблемы объекта Всемирного природного наследия - оз. Байкал требуют экологически ориентированного использования экосистем самого объекта и его бассейна $[1,2]$. Почва является составной частью экосистем. До настоящего 
времени отсутствовали карты почвенного покрова этой территории, созданные на едином методологической подходе и с использованием общих принципов классификации почв.

Имеющиеся почвенные карты по бассейну Байкала на территорию России [1, 3] и Монголии [4] отражают этап исследований 1960-1980 гг. При их создании использовались различные методы и номенклатура. Важным этапом в развитии почвенной науки России и Монголии явилось создание почвенной карты бассейна Байкала масштаба 1:5000 000 [5]. Основой для составления карты послужили многолетние почвенные исследования, проведенные в 1990-2017 гг. в Бурятии, Иркутской области, Забайкальском крае и Монголии [6-9] с использованием современного картографического инструментария [10-12]. Географическое представление почвенного покро- ва с использованием новой классификации почв [13, 14] является одним из первых опытов в России. В данной работе рассматриваются основные закономерности пространственной организации почв Байкальского региона. Площади ассоциаций почв подсчитаны в программе MapInfo.

\section{Материалы и методы исследования}

Объектом исследования является почвенный покров бассейна о3. Байкал (площадь 576,5 тыс. км², протяженность по меридиану 13000 км). В южной части бассейн обрамляют Большой Хангайский, Хэнтэйский хребты и Прихубсугульские горные сооружения, на севере - Становое нагорье и Прибайкальские хребты. Среднегорьем занято примерно $45 \%$ территории бассейна [2]. В пределах Российской Федерации находится около половины $(44,6 \%)$ площади байкальского водосбора.

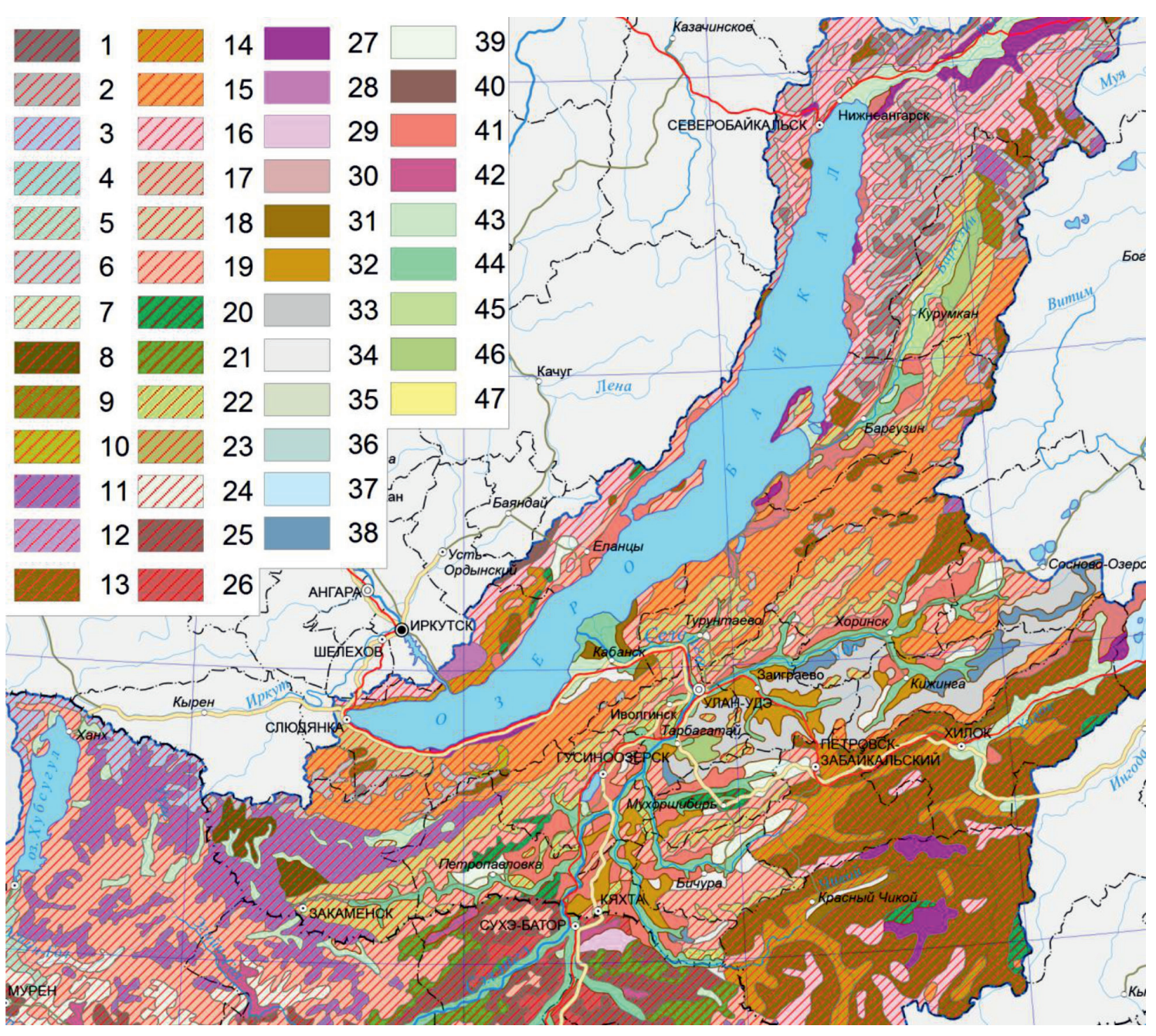

Фрагмент карты «Почвы бассейна оз. Байкал» 
В связи с этим и наряду с данными многолетних исследований почв и почвенного покрова российских и монгольских ученых основой для составления почвенной карты бассейна оз. Байкал послужили различные картографические материалы, отражающие климат, рельеф, геологию, геоморфологическое строение и пространственную организацию почвенного и растительного покровов, использовались разные по масштабу и времени издания топографические карты, аэро- и космические снимки, а также результаты полевых маршрутных исследований авторов. При этом учитывались факторно-индикационные характеристики и почвенно-ландшафтные связи [15].

Главными факторами, определяющими пространственную организацию почвенного покрова в регионе на мегауровне, являются рельеф и климат. Указанные факторы и ландшафтные связи имеют отчетливую специфику в горной и равнинной частях бассейна. Влияние акватории озера Байкал также определяет особенности климата и, соответственно, почвенного и растительного покрова. В связи с этим отдельно рассматриваются почвы высокогорий, высоких равнин, межгорных понижений и Прибайкалья.

В условиях горного рельефа преобладающими типами СПП являются мозаики и сочетания. В днищах межгорных котловин встречаются комплексы. Однако такие черты рельефа, как выположенные вершины хребтов, щебнистые днища котловин и большой диапазон показателей крутизны склонов, значительно усложняют структуру почвенного покрова и нередко обусловливают одновременное чередование сочетаний и мозаик. В связи с этим на карте даны ассоциации почв, состоящие из трех групп: «основные», «сопутствующие» и «встречающиеся» (карта) без указания классов почвенных комбинаций [5] (рисунок, таблица). К основным относятся преобладающие почвы, занимающие 70-80\% территории, к сопутствующим - занимающие 15-20\% территории и к встречающимся - 5-10\%.

\section{Результаты исследования и их обсуждение}

Процессы почвообразования тесно связаны с корами выветривания. В Северной Монголии сочетаются грубообломочная ортоэлювиальная, карбонатная и хлоридносульфатная коры выветривания, в Селенгинском среднегорье на склонах хребтов выражена также обызвесткованная щебнистая кора, в Прибайкалье на склонах, обра- щенных к озеру, грубообломочный ортоэлювий сменяется кислой сиаллитной корой выветривания.

Почвы высокогорной, среднегорной, низкогорной и котловинной частей территории имеют свои особенности. Для Хангайского хребта характерна следующая смена почв от верхнего пояса к подножью: литоземы $\rightarrow$ торфяно-глееземы $\rightarrow$ криоземы $\rightarrow$ дерново-подбуры $\rightarrow$ черноземы дисперснокарбонатные. Литоземы доминируют в водораздельной альпинотипной части с сопутствующими им петроземами, глееземами и подбурами. Ниже, в лесотундровом и таежном поясе со сглаженными формами рельефа и небольшими перепадами высот формируются торфяно-глееземы и насыщенные влагой неглубоко протаивающие криоземы на льдистой мерзлоте, с сопутствующими на повышениях сухо-мерзлотными подбурами и, локально по микропонижениям, - торфяно-литоземами. Завершается поясность дерново-подбурами с сопутствующими им серогумусовыми почвами и черноземами дисперсно-карбонатными. В горной тайге Хангая встречаются степные «острова» с почвами черноземного облика: литоземы перегнойно-темногумусовые и темногумусовые, иногда темногумусовые типичные почвы, а также каштановые и криоаридные почвы. Их можно встретить на крутых участках склонов южной экспозиции. По заболоченным понижениям формируются торфяные эутрофные почвы.

Горы Хэнтэйского нагорья имеют пологий рельеф с широким распространением останцов, скал и каменистых россыпей. В вертикальной поясности смена основных типов почв представлена рядом: криоземы $\rightarrow$ литоземы $\rightarrow$ дерново-подбуры $\rightarrow$ темногумусовые метаморфизированные. В водораздельной части криоземам сопутствуют сухо-мерзлотные подбуры. В подтаежном поясе на рыхлом элюво-делювии доминирующими типами почв являются дерново-подбуры и сопутствующие им серогумусовые почвы. Многочисленные выходы плотных пород с маломощным элювием обусловливают формирование литоземов серогумусовых и петроземов гумусовых. Локально встречаются торфяно-литоземы. В северной части Хэнтэйского нагорья на территории России (Чикойский хребет, максимальная высота 2519 м), смена почв по поясам более проста и состоит из двух типов: подбуры грубогумусированные $\rightarrow$ подбуры, грубогумусовые почвы $\rightarrow$ дерново-подбуры. Подбурам грубогумусированным сопутствуют буроземы 
и подбуры оподзоленные по долинам рек, дерново-подбуры образуют комбинации с серогумусовыми почвами. На высоких равнинах встречаются подзолы и темногумусовые типичные почвы.

В вертикальной структуре западной части Прихубсугулья отмечается следующая смена почв: литоземы $\rightarrow$ криоземы $\rightarrow$ дерново-подбуры, а восточнее, в пределах Джидино-Хамар-Дабанской части: карболитоземы $\rightarrow$ криоземы $\rightarrow$ подбуры $\rightarrow$ дерново-подбуры.

В водораздельной части хребтов Прибайкалья в пределах гольцового пояса под лишайниковыми и травянистыми сообществами среди каменистых россыпей доминируют петроземы и литоземы. В подгольцовом поясе под зарослями кедрового стланика самостоятельную полосу занимают литоземы и петроземы с подбурами и подзолами. В пределах горной тайги Северного Прибайкалья ниже гольцового пояса формируются альфегумусовые почвы с элювиально-иллювиальным дифференцированным, слабодифференцированным и недифференцированным профилями. На Байкальском, Баргузинском хребтах и в Северо-Байкальском нагорье господствуют подзолы и подбуры с участием торфяноподбуров и дерново-подзолов. В вертикальной поясности образуются ряды, в нижней части которых имеются отличия на склонах разной экспозиции: литоземы и петроземы $\rightarrow$ подбуры и подзолы $\rightarrow$ дерново-подзолы глеевые (склон, обращенный к побережью Байкала), подбуры, грубогумусовые и дерново-подбуры (склон, обращенный к Баргузинской котловине).

В высокогорной части хребтов Хамар-Дабан, Улан-Бургасы и Икатский наибольшую площадь занимают подбуры и буроземы грубогумусовые. Под субальпийскими лугами формируются органо-аккумулятивные, прежде всего темногумусовые почвы. На склонах, обращенных к Байкалу, буроземы спускаются к основанию хребтов и смена почв в вертикальной поясности представлена рядом: темногумусовые $\rightarrow$ подбуры $\rightarrow$ буроземы. В нижней части склонов восточной экспозиции в предгорной тени последовательно располагаются пояса подбуров и грубогумусовых почв и дерново-подбуров, образуя ряд: темногумусовые $\rightarrow$ подбуры $\rightarrow$ подбуры и грубогумусовые $\rightarrow$ дерново-подбуры.

Межгорные котловины Прибайкалья характеризуются большой пестротой почвенного покрова от таежных и болотных до сухостепных, что обусловлено широтным положением, высотой, орографической барьерностью, экспозиционностью склонов окружающих горных хребтов и особенностями влияния акватории озера. В дельте p. Селенга, в долине рек Баргузин и Северная Ангара относительно крупные массивы заняты болотами, на которых развиваются преимущественно торфяные эутрофные и торфяные эутрофные глеевые почвы. В устьях рек Баргузин и Турка формируются дерново-подзолы, в устье р. Селенга дерново-подбуры и дерново-серые почвы. Для побережья оз. Байкал одновременно с оподзоленными и болотными почвами, характерно формирование псаммоземов. В Приольхонье и на о. Ольхоне, а также в Баргузинской котловине в дождевой тени Приморского, Байкальского и Баргузинского хребтов формируются сухостепные каштановые, серо- и светлогумусовые почвы. В Баргузинской котловине широко распространены засоленные почвы, в том числе солончаки, временами встречаются солонцы и солонцеватые почвы.

Орхон-Селенгинское и Селенгинское среднегорья представляют собой вытянутые с юго-запада на северо-восток крупные межгорные понижения с отметками в днищах 500-1000 м, к окраинам 1000-1500 м, чередующиеся с останцами высотой до 1500-2000 м. Высокие гипсометрические отметки окружающих горных сооружений вызывают аридный котловинный эффект, благодаря которому в днищах котловин формируются сухостепные почвы. На территории Монголии значительные территории заняты каштановыми, криоаридными и светлогумусовыми почвами. Им сопутствуют и вместе с ними встречаются каштановые гидрометаморфизированные и криогумусовые почвы. По долинам рек формируются серо- и светлогумусовые почвы с относительно небольшими контурами засоленных почв. По окраинам среднегорья в подтаежном ландшафтном поясе (1650-1900м) Хангайского, Хэнтэйского и прихубусугульских хребтов, ближе к обрамляющим его высокогорным хребтам, в почвенном покрове встречаются темногумусовые типичные и метаморфизированные почвы. Переходные к горной части территории занимают дерново-подбуры с сопутствующими им серогумусовыми почвами, а также дисперсно-карбонатные и гидрометаморфизированные черноземы. По пологим склонам солярной экспозиции каштановые и криоаридные почвы поднимаются в горы. 


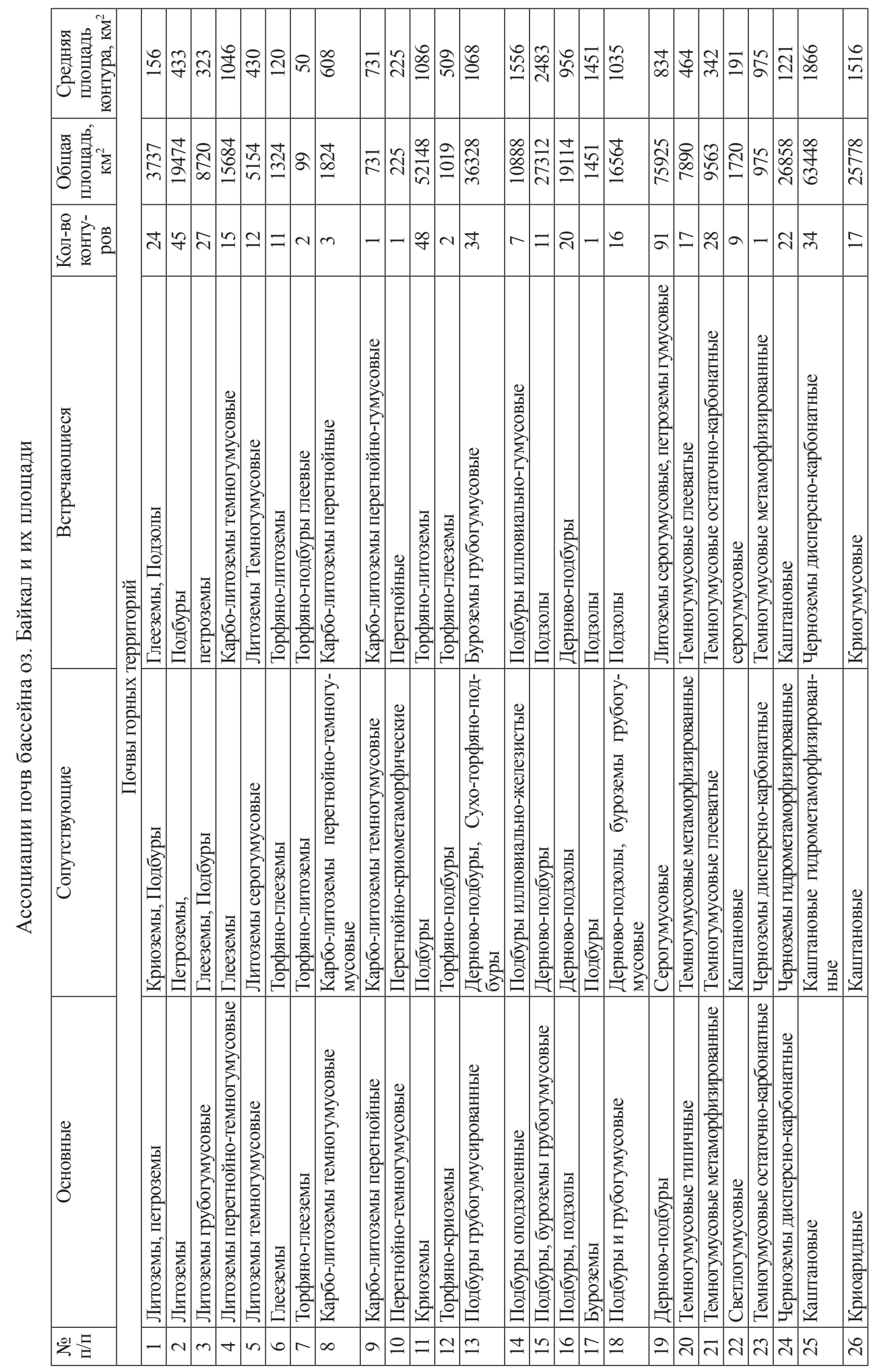




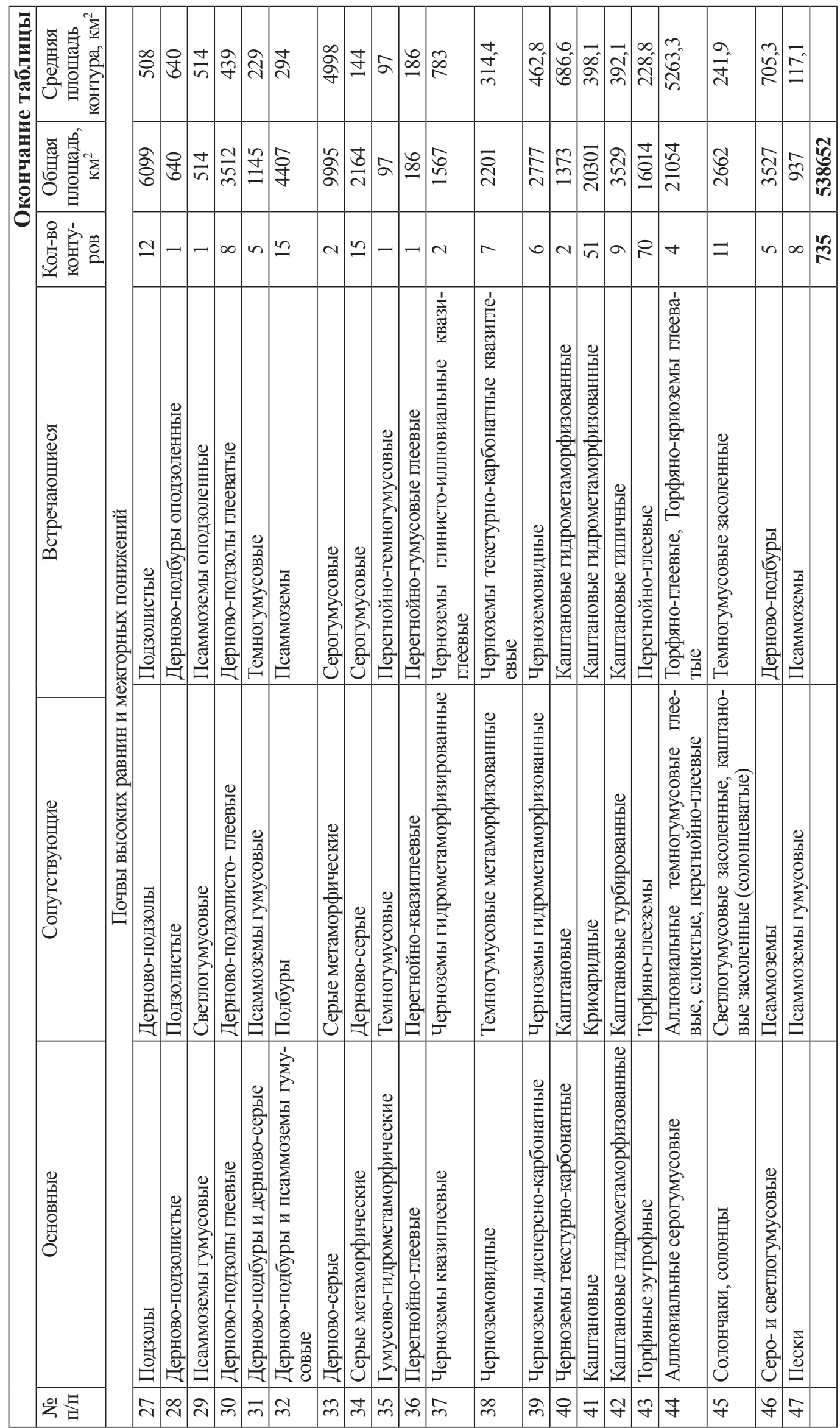


Преобладающими почвами российской части Селенгинского среднегорья являются дерново-серые и каштановые почвы. Дерново-серые доминируют в северо-восточной части среднегорья. По остепненным лугам на речных террасах значительные территории занимают почвы черноземного облика: черноземовидные, темногумусовые метаморфизованные и собственно черноземы текстурно-карбонатные квазиглеевые. На песчаных отложениях широко распространены комбинации дерново-подбуров и псаммоземов гумусовых. В сторону окружающих хребтов в почвенном покрове увеличивается доля дерново-подбуров и серогумусовых почв. Они занимают средние и нижние, преимущественно пологие, части склонов и днища котловин, покрытые сосновыми, смешанными и мелколиственными лесами.

В пределах Иволгино-Гусиноозерской части среднегорья и далее на юг увеличиваются площади, занятые каштановыми почвами и комбинациями дерново-подбуров и псаммоземов гумусовых. Сопутствующими почвами в пределах котловин являются серые метаморфические. Небольшие ареалы заняты черноземами квазиглеевыми. По долинам р. Хилок и ее притока - p. Тугнуй значительные площади занимают черноземы дисперсно-карбонатные и темногумусовые почвы. Для нижней части пологих склонов и приозерных понижений характерны обширные массивы засоленных почв, распространенные в Иволгинской, Тугнуйской и Бичурской котловинах и Боргойской степи. Занимают они понижения, в основном прилегающие к поймам рек. Наиболее распространенные типы засоления солонцов и солончаков - сульфатно-содовый, содовосульфатный, сульфатный и хлоридно-сульфатный.

Пойменные почвы представлены в основном аллювиальными светло-, серои темногумусовыми почвами; на островах и в прибрежной части - слаборазвитыми аллювиальными слоистыми почвами. В степной и особенно в сухостепной зонах Забайкалья, в поймах рек также формируются солончаки и реже солонцы.

Пойма р. Баргузин занята аллювиальными серо- и темногумусовыми почвами, образующими комбинации с торфяно-глеевыми и торфяно-криоземами глееватыми. В дельте р. Селенга в пределах Усть-Селенгинской впадины в основном формируются аллювиальные серогумусовые, темногумусовые, слоистые и оторфованные почвы. Основ- ные закономерности отражены в 47 ассоциациях почв (таблица).

Основные закономерности пространственного распределения почв бассейна оз. Байкал, имеющего протяженность 13000 км по меридиану, во многом связаны с широтной зональностью. Однако различия в поступлении солнечной радиации между параллелями $46^{\circ}$ и $57^{\circ}$ в значительной мере нивелируются горным характером рельефа с его вертикальной поясностью.

Почвенные контуры с подбурами в качестве основных компонентов ассоциаций

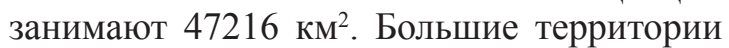

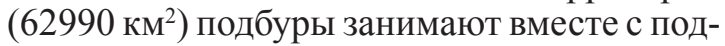
золами, буроземами и грубогумусовыми почвами. Преобладание подбуров в почвенном покрове северной части бассейна отражает зонально-фациальные закономерности распределения почв. Сложность почвенного покрова горно-таежных ландшафтов Прибайкальских хребтов, формирование в качестве основных типов наряду с подбурами подзолов и буроземов обусловлено влиянием оз. Байкал. В межгорных понижениях Прибайкалья отмечается большая пестрота почвенного покрова, обусловленная поступлением влаги с окружающих горных хребтов, сложный рельеф, включающий современные и древние русла рек, низины и террасы. Несмотря на это от северного Прибайкалья к южному все же прослеживается последовательная смена преобладания болотных торфяных эутрофных почв дерново-подзолами, подтаежными дерново-серыми почвами и дерново-подбурами.

Преобладающим типом почв таежного пояса гор южной части бассейна, Малого Хамар-Дабана, прихубсугульских хребтов, Хэнтэя и Хангая, являются льдисто-мерзлотные представители почв, ранее объединенных под названием мерзлотно-таежные - криоземы $\left(\mathrm{S}=52148\right.$ км$\left.^{2}\right)$. Вместе с криоземами здесь широко распространены почвы влажных экологических ниш литоземы перегнойно-гумусовые и торфяно-глееземы. Большую роль в создании гумидного климата и накопления льдистой мерзлоты здесь играет большая высота (2500-3500 м над у.м.), огромные площади $(>$ млн км²), занимаемые этими горными странами, и значительное поступление солнечной радиации.

Значительные площади на территории бассейна оз. Байкал занимают дерновоподбуры - почвы переходных от горно-таежных к степным ландшафтов. В качестве основных компонентов ассоциаций они 
распространены по всей территории бассейна и занимают территорию в 75925 км². Дерново-подбуры в качестве основных типов образуют комбинации с дерново-серыми почвами (1145 км²) и с псаммоземами гумусовыми (4407 км²). В северной части бассейна дерново-подбуры формируются в основном на высотах 700-800 м, поднимаясь в горы в дождевой тени и по склонам солярных экспозиций до высоты 1000 м, а в южной - на высоте 1000-1500 м и поднимаются в горы до отметок 1750 м.

Почвенный покров Селенгинского и Орхон-Селенгинского среднегорья характеризуется следующей сменой доминирующих типов почв с севера на юг:

а) дерново-серые с участками черноземовидных почв;

б) каштановые;

в) горно-каштановые и криоаридные.

Контуры, где основным типом являются дерново-серые почвы, имеют площадь

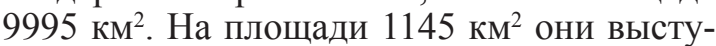
пают фоном вместе с дерново-подбурами. Местоположение дерново-серых почв приурочено к северной части Селенгинского среднегорья, граничащей с областью распространения многолетней мерзлоты. Почвы формируются на песчано-пылеватых лессовидных отложениях в нижней части пологих склонов или на речных террасах под смешанными или мелколиственными лесами. Тип дерново-серые выделен Ц.Х. Цыбжитовым [16]. Генезис и классификационное положение этих почв окончательно не выяснено.

Доминирующими в среднегорье являются каштановые почвы. В качестве основных они входят в контуры общей пло-

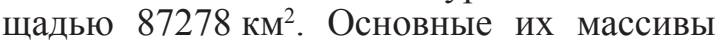
располагаются в южной части среднегорья, охватывая пенепленизированные поверхности древних хребтов и террасы рек Тугнуй, Хилок, Чикой, Джида, Селенга, Орхон, Хунуйн Гол, Шарын Гол и др. География каштановых почв включает также Баргузинскую котловину, о. Ольхон, Приольхонье. В верховьях рек Идэр и Дэлгэр-Мурэн на Хангае на высоте 2000 м развиваются неполнопрофильные светлогумусовые почвы. В степных ландшафтах формируются также криоаридные почвы, имеющие сходство с каштановыми почвами. Для их окончательной диагностики требуются специальные исследования.

География дерново-серых и каштановых почв свидетельствует о том, что эти почвы можно отнести к зональным. До- казательством служит строгая приуроченность дерново-серых почв к бореальной области в северной части Селенгинского среднегорья, где они являются фоновыми. Что касается каштановых почв, то они абсолютно доминируют в суббореальной области Селенгинского и Орхон-Селенгинского среднегорья. Формирование их в понижениях среди высокогорий объясняется спецификой горного почвообразования и демонстрирует экспансивный характер распространения засушливых почв на территории бассейна оз. Байкал.

Черноземы являются зональными почвами на территории Восточной Европы и Западной Сибири. На территории Забайкалья и Северной Монголии они не образуют крупных контуров. В Монголии эти почвы приурочены к предгорьям Хангая, где они поднимаются до высоты 1750 м и располагаются ниже пояса дерново-подбуров. На российской территории черноземы формируются отдельными участками, приуроченными к нижней части и подножиям склонов теневых экспозиций южной части Селенгинского среднегорья и примыкающим к ним днищах котловин. Распространение черноземов в бассейне оз. Байкал аналогично дерново-подбурам, которые образуют пояс в предгорьях Хангая, Прибайкальских хребтов, Хэнтэя и Чикоя. Площадь черноземов составляет 32575 км²$^{2}$, а география их определяется в первую очередь вертикальной поясностью и экспозиционностью, нежели широтной зональностью.

В поймах формируются различные типы почв, относящиеся к отделам слаборазвитых, аллювиальных, галоморфных почв. Специфика пойменного почвообразования связана с горным характером территории, региональными особенностями поемноаллювиальных процессов, резко континентальным климатом и функционированием почв в условиях совместного проявления криодизации и аридизации. Почвенный покров континентальной дельты Селенги характеризуется неоднородностью. На песчаных плейстоценовых озерно-речных террасах развиваются дерново-подбуры и дерново-серые почвы, на пологонаклонных участках террас - серые метаморфические, на древней дельте - торфяные эутрофные почвы.

\section{Заключение}

На карте почвенного покрова бассейна о3. Байкал на территории России и Монголии отражены основные закономерности 
пространственного распределения почв. Составленная карта является документом, отражающим количество и качество почвенных ресурсов и необходима для учета и оценки биосферных функций почв этой территории, влияния почвенного покрова на о3. Байкал и имеет большое значение для планирования развития сельского хозяйства в России и в Монголии.

Территория бассейна оз. Байкал расположена выше 455 м над уровнем моря и состоит из высокогорий и среднегорий, имеющих отчетливые отличия и специфичность проявления широтной зональности. Наличие горных систем и их обширные пологонаклонные предгорья сглаживают контрасты в смене ландшафтов и почв в широтной зональности. При рассмотрении элементов вертикальной поясности отмечается преобладание в высокогорьях северной части сухомерзлотных почв, а южной - льдистомерзлотных, обусловленное более высокими температурами, обусловливающими накопление влаги в виде льда. Среди почв высокогорий северной части бассейна господствуют подбуры, а южной - криоземы.

В Северном Прибайкалье наряду с подбурами доминируют подзолы. В Восточном и Южном Прибайкалье формируются буроземы, что объясняется смягчающим влиянием оз. Байкал на климат этой территории. Дерново-подбуры являются элементом вертикальной поясности почв с самым крупным ареалом и представляют собой переходный тип почв от горно-таежных к степным. В северной российской части бассейна широко распространены комбинации подбуров с дерново-подбурами и буроземами. Их «зональность» заключается в том, что спорадически встречаясь на северной границе бассейна, они расширяют свой ареал к югу в соответствии с аридизацией климата и увеличением площадей горных областей. В среднегорье, пересекающем территорию бассейна о3. Байкал непрерывной полосой, расширяющейся от Витимского плоскогорья до Хангая, широтная зональность почв прослеживается более отчетливо и включает дерново-серые почвы, каштановые и криоаридные.

Исследования выполнены по теме проектов НИР № АAАA-A17-117011810038-7 (ФАHO 0337-2017-0002); № AAAA-A17117041910169-4 (ФАНО 0347-2016-0002).

\section{Список литературы}

1. Байкал. Атлас. - М., ГУК, 1993. - 160 с.

2. Экологический атлас бассейна озера Байкал. - Иркутск: Изд-во Института географии им. В.Б. Сочавы СО PAH, 2015. - $145 \mathrm{c}$.
3. Почвенный покров Бурятской АCCP. М-б 1:1 000 000. - М.: ГУГК, 1980.

4. Национальный атлас Монголии. - Улан-Батор - Москва, 1990. - 144 с

5. Белозерцева И.А., Доржготов Д., Батхишиг О., Убугунов Л.Л., Бадмаев Н.Б., Убугунова В.И., Гынинова А.Б., Балсанова Л.Д., Убугунов В.Л., Гончиков Б.Н., Цыбикдоржиев Ц.Д-Ц., Сороковой А.А. Почвы // Экологический атлас бассейна озера Байкал. Карта 1:5000000 Мб. - Иркутск: Ин-т географии им. В.Б. Сочавы СО РАН, 2015. - С. 38-40.

6. Доржготов Д., Батхишиг О. Почвы. Почвенно-географическое районирование Монголии // Национальный Атлас Монголии. - Улан-Батор, 2009. - С. 120-122.

7. Краснощеков Ю.Н. Почвенный покров и почвы горных лесов северной Монголии. - Новосибирск: Наука, 2013. $-196 \mathrm{c}$

8. Убугунов В.Л., Убугунова В.И. Почвообразующие породы - как ключ к пониманию самобытности почвообразования в Западном Забайкалье // Природа Внутренней Азии. - 2017. - № 4. - С. 37-50. DOI: 10.18101/2542-06232017-4-37-50.

9. Убугунов Л.Л., Убугунова В.И., Бадмаев Н.Б., Гынинова А.Б., Убугунов В.Л., Балсанова Л.Д. Почвы Бурятии: разнообразие, систематика и классификация // Вестник Бурятской государственной сельскохозяйственной академии им. В.Р. Филиппова. - 2012.- № 2. - С. 45-52.

10. Алябина И.О. Оценка роли почвообразующего потенциала природных факторов в формировании почвенного покрова на основе геоинформационных технологий: автореф. дис. ... докт. биол. наук. - Москва. 2016. - 51 с.

11. Рухович Д.И., Королева П.В., Вильчевская Е.В., Калинина Н.В. Цифровая почвенная картография как смена доступных первоисточников и способов их использования // Цифровая почвенная картография: теоретические и экспериментальные исследования. - М.: Почвенный институт им. В.В. Докучаева. - 2012. - С. 58-87.

12. McBratney A.B., Mendoca-Santos M.L., Minasny B. On digital soil mapping // Geoderma. - 2003. - Vol. 117. - Issue 1-2. - P. 3-52.

13. Воробьева Г.А. Почвы Иркутской области: вопросы классификации, номенклатуры и корреляции. - Иркутск: Изд-во Иркут. гос. ун-та, 2009. - 149 с.

14. Шишов Л.Л., Тонконогов В.Д., Лебедева И.И., Герасимова М.И. Классификация и диагностика почв России. 2018. URL: http://soils.narod.ru/obekt/obekt.html (дата обращения: 15.04.2018).

15. Соколов И.А. Пространственно-временная организация педосферы и ее эволюционно-экологическая обусловленность // Почвоведение. - 1993. - № 7. - С. 13-22.

16. Цыбжитов Ц.Х., Цыбикдоржиев Ц.Ц., Давыдова М.А., Гончиков Б.М.Н. Структура почвенного покрова Тугнуйской котловины Забайкалья // Почвоведение. 2008. - № 8. - C. 928-936.

\section{References}

1. Bajkal. Atlas. M., GUK, 1993. 160 p.

2. EHkologicheskij atlas bassejna ozera Bajkal. Irkutsk: Izdvo Instituta geografii im. V.B. Sochavy SO RAN, 2015. 145 p.

3. Pochvennyj pokrov Buryatskoj ASSR. M-b 1: 1000000. M.: GUGK, 1980.

4. Nacional'nyj atlas Mongolii, Ulan-Bator - Moskva, 1990. 144 p.

5. Belozerceva I.A., Dorzhgotov D., Bathishig O., Ubugunov L.L., Badmaev N.B., Ubugunova V.I., Gyninova A.B., Balsanova L.D., Ubugunov V.L., Gonchikov B.N., Cybikdorzhiev C.D-C., Sorokovoj A.A. Pochvy // EHkologicheskij atlas bassejna ozera Bajkal. Karta 1:5000000 Mb. Irkutsk: In-t geografii im. V.B. Sochavy SO RAN. 2015. pp. 38-40.

6. Dorzhgotov D., Batkhishig O. Pochvy. Pochvennogeograficheskogo raionirovanie Mongolii [Soils. Soil and geographical division into districts of Mongolia]. Natsional'nyi At- 
las Mongolii [National Atlas of Mongolia]. Ulaanbaatar, Institut geografii akademii nauk Mongolii, 2009, pp. 120-122.

7. Krasnoshchekov Iu.N. Pochvennyi pokrov i pochvy gornykh lesov severnoi Mongolii [Soil cover and soils of the mountain woods of northern Mongolia]. Novosibirsk, Nauka, 2013, 196.

8. Ubugunov V.L., Ubugunova V.I. Soil-forming rocks are the key to understanding the soil formation uniqueness in West Transbaikalia [Pochvoobrazuiushchie porody - kak kliuch $\mathrm{k}$ ponimaniiu samobytnosti pochvoobrazovaniia $\mathrm{v} \mathrm{Za}$ padnom Zabaikal'e. 2017. № 4. pp. 37-50]. Priroda Vnutrennei Azii - Nature of Inner Asia, 2017, no. 4, pp. 37-50. DOI: 10.18101/2542-0623-2017-4-37-50.

9. Ubugunov L.L., Ubugunova V.I., Badmaev N.B., Gyninova A.B., Ubugunov V.L., Balsanova L.D. Soils of Buryatia: variety, systematization and classification [Pochvy Buriatii: raznoobrazie, sistematika i klassifikatsiia]. Vestnik Buriatskoi gosudarstvennoi sel'skokhoziaistvennoi akademii im. V.R. Filippova - Bulletin of the Buryat state agricultural academy of V.R. Filippov, 2012, no. 2, pp. 45-52.

10. Aliabina I.O. Otsenka roli pochvoobrazuiushchego potentsiala prirodnykh faktorov $\mathrm{v}$ formirovanii pochvennogo pokrova na osnove geoinformatsionnykh tekhnologii: avtoref. dis.

... dokt. biol. nauk [Assessment of a role of pochvoobrazuyushchy potential of natural factors in formation of a soil cover on the basis of geoinformation technologies: abstract of the Dr.Sci. Biol.]. Moscow, MGU, 2016, 51.
11. Ruhovich D.I., Koroleva P.V., Vil'chevskaya E.V., Kalinina N.V. Cifrovaya pochvennaya kartografiya kak smena dostupnyh pervoistochnikov i sposobov ih ispol'zovaniya// Cifrovaya pochvennaya kartografiya: teoreticheskie i ehksperimental'nye issledovaniya. M.: Pochvennyj institut im. V.V. Dokuchaeva. 2012. pp. 58-87.

12. McBratney A.B., Mendoca-Santos M.L., Minasny B. On digital soil mapping. Geoderma, 2003, vol. 1, no. 117, pp. 3-52.

13. Vorob'eva G.A. Pochvy Irkutskoi oblasti: voprosy klassifikatsii, nomenklatury i korreliatsii [Soils of the Irkutsk region: questions of classification, nomenclature and correlation]. Irkutsk, IGU, 2009, 149.

14. Shishov L.L., Tonkonogov V.D., Lebedeva I.I., Gerasimova M.I. Klassifikatsiia i diagnostika pochv Rossii [Classification and diagnostics of soils of Russia]. Available at: http://soils. narod.ru/obekt/obekt.html (accessed 09.04.2018).

15. Sokolov I.A. Existential organization pedosfer and its evolutionary and ecological conditionality [Prostranstvennovremennaia organizatsiia pedosfery i ee evoliutsionno-ekologicheskaia obuslovlennost']. Pochvovedenie - Soil science, 1993, no. 7, pp. 13-22.

16. Tsybzhitov Ts.Kh., Tsybikdorzhiev Ts.Ts., Davydova M.A., Gonchikov B.M.N. Soils cover patters in the Tugnuisk Depression of The Transbaikal Region [Struktura pochvennogo pokrova Tugnuiskoi kotloviny Zabaikal'ia]. Pochvovedenie Eurasian Soil Science, 2008, no. 8, pp. 928-936. 